\title{
Introduction
}

\section{Contextualising Choices: Islamicate Elements in European Arts}

\section{Vera Beyer and Isabelle Dolezalek*}

Perched high up on a ladder, the nineteenth-century scholar Charles Drury Edward Fortnum found to his irritation that the blue ceramic bacino he was about to detach from its centuries-old setting in the façade of a Pisan church was not Italian, but a bowl of 'Persian' manufacture (Figure 1). ${ }^{\text {' }}$ Four centuries earlier, the Ifriqiyan scholar Ibn Naji al-Tanukhi, instead, had proudly enumerated a whole array of Eastern materials and artefacts brought to Kairouan; ${ }^{2}$ among these were a set of precious lustre-tiles used to decorate the façade of the Great Mosque's mihrāa (Figure 2). ${ }^{3}$

\footnotetext{
${ }^{1}$ Drury Fortnum, "Notes on the "Bacini”": 383. Fragments of this bowl from the church of Santa Cecilia are preserved in the Museo Nazionale di San Matteo in Pisa, the Ashmolean Museum Oxford and the British Museum in London. It has been classified as Raqqa ware.

2 'They had imported for him these precious tiles for a reception hall which he wished to construct, and they (had) imported for him from Baghdad teak wood to be made into lutes, which he made into a pulpit for the Great Mosque. And he had the mihrab brought from Iraq in the form of panels of marble; he constructed this mihrāb in the Great Mosque of Kairovan, and placed these faience tiles ( qāramīd) on the façade of the mihrāa b [...].' Translation in Creswell, A Short Account of Early Muslim Architecture: 326.

${ }^{3}$ We would like to gratefully acknowledge that we owe these examples to two summer schools, one in Tunisia and the other in Pisa and Sardinia, held by the Kunsthistorisches Institut in Florence and initiated by Hannah Baader, Avinoam Shalem and Gerhard Wolf.

* Institute of Art History, Free University of Berlin, DFG Emmy Noether Junior Research Group 'Kosmos/Ornatus. Ornaments in Persia and France c. 1400 in Comparison'. E-mails: vera.beyer@fu-berlin.de; i.dolezalek@fu-berlin.de
}

The Medieval History Journal, 15,2 (2012): 231-242

SAGE Publications Los Angeles/London/New Delfi/Singapore/Wasfington DC DOI: $10.1177 / 097194581201500201$ 
232 - Vera Beyer and Isabelle Dolezalek

Figure 1

Bacino fragment, Pisa, Santa Cecilia

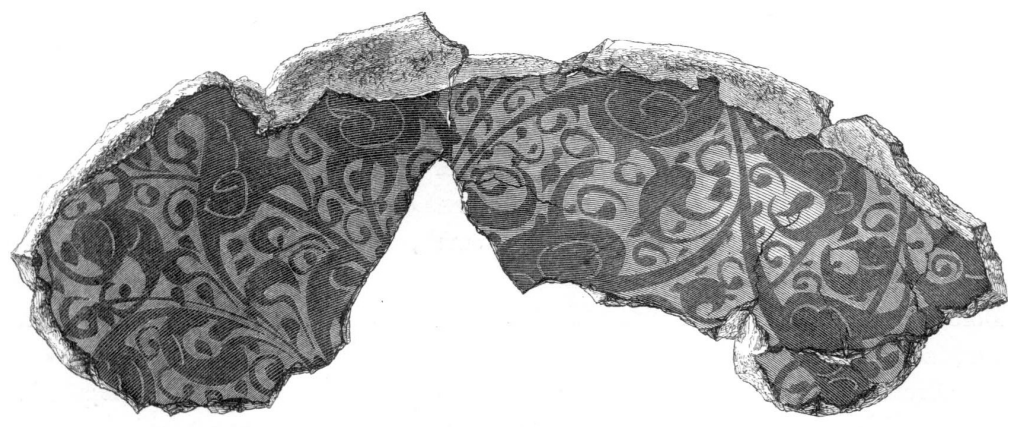

Figure 2

Lustre-tiles, Great Mosque of Kairouan, detail of the mihrāb

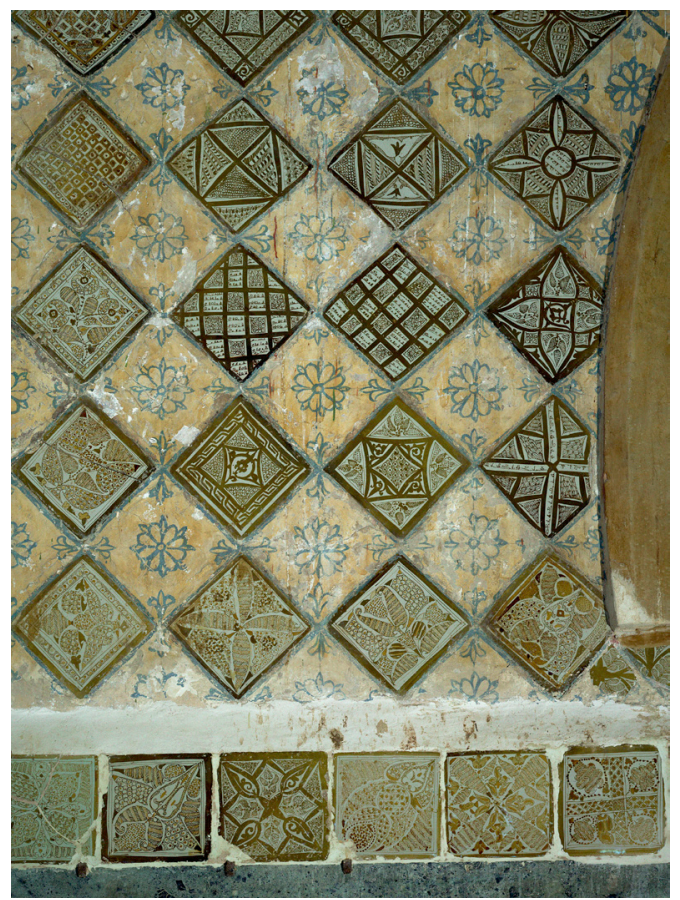

- The Medieval History Journal, 15, 2 (2012): 231-242 
While later commentators' appraisals of Islamicate ceramics in Western contexts differ, the two examples above show that there was a widespread taste for Eastern artefacts across the cultural and religious divides of the medieval Mediterranean. ${ }^{4}$ Islamicate ceramics - particularly lusterwareswere desirable commodities that circulated among the elites. They were highly prized not only for their aesthetic qualities, but also because in medieval Pisa and Kairouan, for instance, the lusterware technique could not be reproduced. ${ }^{5}$

In recent literature, this common taste has been analysed as part of a shared secular court culture in the medieval Mediterranean. ${ }^{6}$ Considering the Ifriqiyan tiles and Pisan bacini from this perspective offers important alternatives to an idea of clear-cut cultural entities, as well as to the triumphalist overtones of the formerly often voiced assumption that Islamicate objects in Christian contexts were booty. ${ }^{7}$

However, this shared culture was not an exclusively secular one. In fact, the examples expose the difficulties created by attempting to project the modern distinction between secular and religious spheres onto medieval contexts. ${ }^{8}$ This is clearly shown by the fact that it was an Ifriqiyan mosque and Pisan churches which were decorated with precious Eastern ceramics. Moreover, the mihrā b of the Great Mosque of Kairouan, an example of religious architecture, was assembled under the patronage of an Aghlabid ruler. In Pisa, on the one hand, religious buildings were very closely associated with political triumph, since they were mostly financed by Pisan victories abroad. The restriction to court culture, on the other hand, is easily undermined here by the fact that there was no court

${ }^{4}$ The Mediterranean as a cultural category has come to the fore in historical studies. See Braudel, La Méditerranée et le monde méditerranéen à l'époque de Philippe II. For methodological impulses regarding Mediterranean art history, see, for example, Wolf, 'Alexandria aus Athen zurückerobern?'.

${ }^{5}$ The circulation of Eastern lustre-ceramics has recently been the subject of a conference: 'The Marvels of the World. Lustreware and Luxury in European Networks of Exchange', Berlin, 17-20 November 2011.

${ }^{6}$ The concept derives from Grabar, 'The Shared Culture of Objects'. Important later contributions on the subject include Hoffman, 'Pathways of Portability'; Tronzo, 'Regarding Norman Sicily'.

${ }^{7}$ For a critical approach to this assumption, see Flood, 'The Medieval Trophy as an Art Historical Trope'.

${ }^{8}$ These categories are assessed, for example, in Dodds, 'Islam, Christianity, and the Problem of Religious Art'; Behrens-Abouseif, 'Beyond the Secular and the Sacred'.

The Medieval History Journal, 15, 2 (2012): 231-242 
in medieval Pisa. Pisa was a republic of merchants in which lustre bacini most likely arrived through trade. The use of fine Eastern ceramics in Pisa and Kairouan is exemplary, therefore, of a historical reality in which objects and forms circulated across modern geographical, political and religious boundaries, thus bringing into question the frames of established art historical categorisation.

This circulation, particularly between Islamic and Christian cultural realms and especially in the Mediterranean, ${ }^{9}$ has been the subject of a growing body of publications which has made a significant contribution to bridging the established institutional gaps between art historical disciplines. ${ }^{10}$ These recent studies have begun to question categorical differences by pointing to the transcultural circulation of objects and forms, thus emphasising continuities, connections and similarities. Within these continuities, the following contributions aim to point to contextual differences. ${ }^{11}$ This volume therefore focuses on the reception of Islamicate elements - objects and forms - in different European contexts by means of case studies which analyse the institutional, regional and social settings for the adaptation of Islamicate elements in medieval European arts. ${ }^{12}$

\footnotetext{
${ }^{9}$ On transfer in the medieval Mediterranean, see, for example, Abdellatif, Benhima, König and Ruchaud (eds), Construire la Méditerranée, penser les transferts culturels; Arcangeli and Wolf(eds), Islamic Artefacts in the Mediterranean World; Robinson and Rouhi (eds), Under the Influence; Ousterhout and Ruggles (eds), Encounters with Islam. Other areas, for example the Caucasus, have received less attention and we regret not having been able to include them.

${ }^{10}$ See Müller-Wiener and Koenen, 'Prolog zum Thema Grenzgänge'; Caskey, Cohen and Safran (eds), 'Confronting the Borders of Medieval Art'. Initiatives to undermine the institutional divides between Byzantine, European, Jewish and Islamic art histories have also been taken in museums through more integrative displays (Ashmolean Museum Oxford 'Mediterranean Galleries'; Victoria and Albert Museum 'The Medieval and Renaissance Galleries') and various temporary exhibitions (Metropolitan Museum of Art, 'Byzantium and Islam: Age of Transition', 14 March-8 July 2012).

${ }^{11}$ Contextualisation as a tool is advocated in two complementary articles on the Artuqidbowl by Ulrike Koenen and Martina Müller-Wiener in Müller-Wiener and Koenen (eds), Grenzgänge im östlichen Mittelmeerraum: 121-46, 147-68; see also Tronzo, 'The Mantle of Roger II of Sicily'; Walker, 'Meaningful Mingling'; Nelson, 'Letters and Language'.

${ }^{12}$ The case studies will show that elements which are considered as 'Islamicate' today were not necessarily perceived as 'foreign' to the cultural contexts subsumed in this volume under the term of Europe. The variety of the European contexts discussed here, moreover, will demonstrate that 'European', as we use it, is not to be understood as a neutral, non-religious denominator of the 'own'. An analysis of the reception of Islamicate arts in contexts other than European ones unfortunately exceeds the scope of this volume, but has recently been addressed, for example, in Flood, Objects of Translation.
}

- The Medieval History Journal, 15, 2 (2012): 231-242 
A contextual case study of the examples we started with, for instance, would have to mention that the Great Mosque of Kairouan was located in a city which, during the reign of the Aghlabid emir Abu Ibrahim Ahmad was bustling with scholars attracted to Kairouan as one of the major centres of culture and learning in the Islamic world. Furthermore, the western reception of the mihrāa 's lustre-tiles would have to be considered within the architectural context of the mosque itself(Figure 3). These tiles, which were probably brought from Baghdad, would have been seen in combination with a variety of imported materials and artefacts, not only of Islamicate provenance, but also for example with spolia from local pre-Islamic monuments. ${ }^{13}$ We would have to ask, therefore, whether their viewers would have been able to identify the origins of these different elements and admire their cosmopolitan references, and to what extent

\section{Figure 3}

Great Mosque of Kairouan, ninth century mihrāb

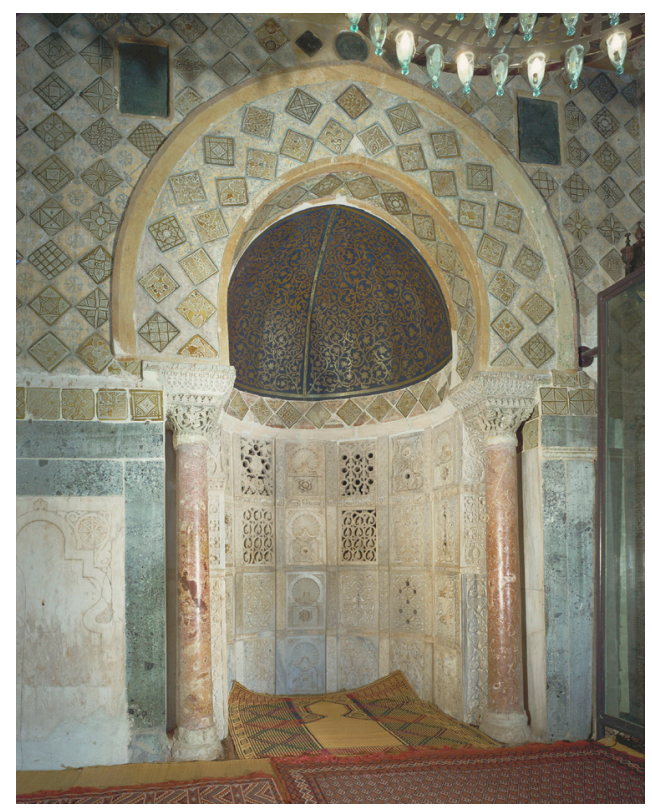

\footnotetext{
${ }^{13}$ On the Great Mosque of Kairouan, see, for example, Lézine, Architecture de l'Ifriqiya; Marçais, Architecture musulmane d'Occident.
}

The Medieval History Journal, 15, 2 (2012): 231-242 
the visual choices in the architecture of the mosque contributed to shaping a local cultural identity. Were the imported and reused elements visual statements with political intent? Did they, for example, symbolically position Aghlabid Kairouan in relation to the Abbasid caliphate to the East and the Umayyad caliphate to the West? Is it significant that Ibn Naji mentions only the 'East' when providing a source for the reception of the Great Mosque's interior in the fifteenth century, omitting to say that the mihräb's marble panelling is signed by a 'Westerner' of Andalusian origin?

The maritime republic of Pisa had widespread trading connections and was eager to extend and demonstrate its commercial and political dominion over the Mediterranean. Entering the city through the Porta del Leone, for instance, foreign visitors would have been greeted by various inscriptions commemorating Pisan triumphs, which were prominently displayed on the façade of the cathedral, constructed using the spoils of the $1063 \mathrm{AD}$ victory against Islamic Palermo. ${ }^{14}$ It is not unlikely in this context that artefacts from Islamic lands would have been displayed as booty and recognised as such. This, incidentally, would support the assumption of Fortnum's nineteenth-century colleagues, whom he was trying to disprove by pointing to the local provenance of the great majority of Pisan bacini (Figure 4). Any case study would have to discuss, however, whether specific Islamicate objects and forms included in Pisan religious architecture were used and perceived as references to the religious antagonists of the Pisan republic, rather than to the political ones, or indeed whether they are indicative of a formal language shared by Mediterranean elites. ${ }^{15}$ The high number of bacini from Islamic regions and their broad chronological and geographic range, moreover, suggest that they were objects of trade rather than diplomatic gifts or spoils of war, ${ }^{16}$ opening the question of how

\section{${ }^{14}$ Smith, The Baptistery of Pisa: 26.}

${ }^{15}$ Examples of Islamicate elements in Pisan architecture include a capital signed Fātih, reminiscent of Cordoban marble carving, now kept in the Museo dell'Opera del Duomo, an opus sectile floor with a pattern reminiscent of Fatimid woodwork in the baptistery and, not the least, the famous bronze griffin also in the Opera del Duomo as well as various bacini.

${ }^{16}$ The vast majority (90.3 per cent) of the bacini decorating the exterior of Pisan churches have been shown to originate from the Western Mediterranean, in particular from Islamic Sicily and the areas corresponding to actual Tunisia and Spain. Ceramics of Egyptian (4.6 per cent) and Byzantine (3.2 per cent) manufacture as well as those from Islamic Near Eastern regions (1.9 per cent) are less well represented. Berti, 'La testimonianza delle ceramiche importate ed esportate': 170.

- The Medieval History Journal, 15, 2 (2012): 231-242 


\section{Figure 4}

Santa Cecilia, Pisa, façade with bacini

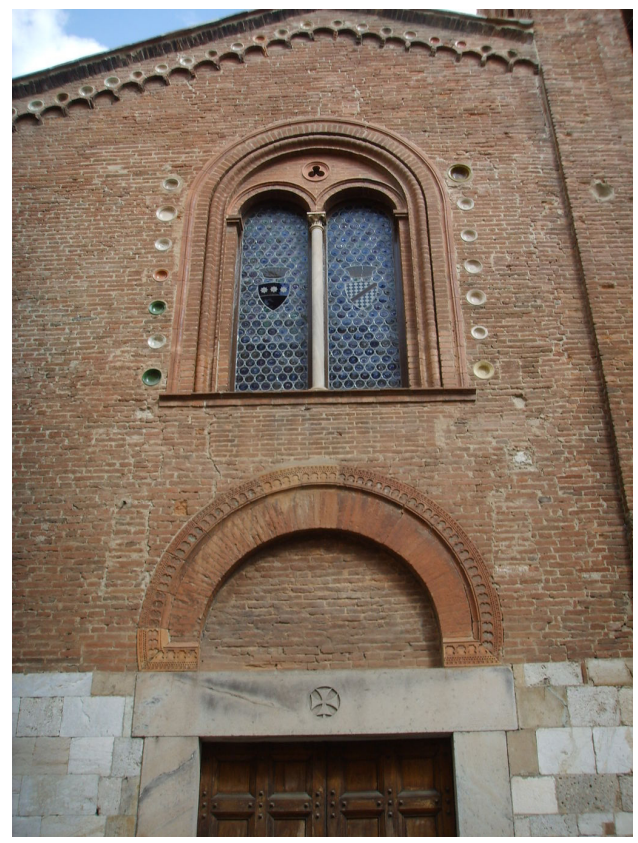

this display of Pisa's commercial connections relates to its expressions of religious and political supremacy.

We raise these questions here without providing answers, yet our two examples of Western receptions of Eastern ceramics emphasise the need for analyses within contextual rather than categorical frames. The varied connotations of these Eastern ceramics cannot be explained in categories, such as Islamic versus Christian, sacred versus profane or courtly versus commercial, but have to be analysed within the contexts of late ninthcentury Aghlabid Kairouan and eleventh- to thirteenth-century Pisa. ${ }^{17}$ The lustre-tiles and ceramics attest to processes of transfer which continuously

${ }^{17}$ Given that the primary scope of this volume is the European reception of Islamicate objects we restrain ourselves here - for the sake of comparability — to the Gregorian dating system.

The Medieval History Journal, 15, 2 (2012): 231-242 
transgress established distinctions and highlight the connections across religious, cultural and regional divides. It is thus all the more important to pinpoint the different choices underlying the reception of transferred objects or forms in a new context, reception being understood here as an active process of choices and adaptations dependent on local interests and projections. ${ }^{18}$

The following case studies of Islamicate elements in European arts thus focus on micro-historical aspects within the transcultural biographies of forms and objects. ${ }^{19}$ Their reception is analysed in specific local contexts, situated within fields of entangled cultural relations. This focus counters a decontextualisation of elements in transcultural circulation; it allows for a consideration of more than bilateral relations and a revision of the internalist assumption of autonomous cultural entities. ${ }^{20}$

Furthermore, as a common denominator of the objects of these studies, we have chosen to use Marshall Hodgson's notion of 'Islamicate', invented to counter a reduction of culture to religious terms. ${ }^{21}$ Hodgson further defines Islamicate in analogy with 'Italianate, in the Italian style, which refers not to Italy itself directly, not to just whatever is to be called properly Italian, but to something associated typically with Italian style and with the Italian manner [...]. ${ }^{\prime 22}$ Correspondingly, we use 'Islamicate' to refer to reception rather than provenance: the articles are much less concerned with reconstructing provenances than with considering the relevance

${ }^{18}$ The notion of reception, as it is used in this volume, does not imply that the contexts in which the objects where produced were homogenous-or indeed homogenously Islamic - and necessarily considered as distinct from the contexts of reception. For a critical assessment of the notion of 'reception', see Müller-Wiener and Koenen, 'Prolog zum Thema Grenzgänge': 24. See also Zeitler, 'Cross-cultural Interpretations of Imagery in the Middle Ages'; Brubacker, 'The Elephant and the Ark'; Shalem, 'Objects as Carriers of Real or Contrived Memories in a Cross-cultural Context'.

${ }^{19}$ The concept of a 'biography of objects', which is relevant to several of the articles in this volume, has been developed in Appadurai (ed.), The Social Life of Things. It is addressed with reference to Islamicate objects, for example, in Contadini, 'Translocation and Transformation'; or Shalem, 'The Second Life of Objects'.

${ }^{20}$ See Eckert and Conrad, 'Globalgeschichte, Globalisierung, multiple Modernen'.

${ }^{21}$ Hodgson, The Venture of Islam: 59: '[...] "Islamicate" would refer not directly to the religion, Islam, itself, but to the social and cultural complex historically associated with Islam and the Muslims, both among Muslims themselves and even when found among non-Muslims.'

${ }^{22}$ Hodgson, The Venture of Islam: 59.

- The Medieval History Journal, 15, 2 (2012): 231-242 
an attribution to geographic or temporal origins may have had-or not had - in the reception of an object or form.

Arabic script on European artefacts, which has often been understood as a marker of Islamic provenance, is one example here. In fact, among the three articles in the volume which touch upon this form, in one case only - an inscribed gemstone on the cover of a gospel manuscript, which Gia Toussaint analyses - was the Arabic inscription presumably produced in an Islamicate context. In the other two cases, the Arabic script was actually produced in Christianate contexts, namely eleventh-century Saxony and twelfth-century Palermo.

On the textile-page with a pseudo-Kufic inscription in the Braunschweig Gospels, discussed by Anna Bücheler, Arabic script seems to have been used to indicate a Near-Eastern provenance. As the author argues, the textile-page is associated with the holy shroud by being placed next to a depiction of the Holy Sepulchre, and its Kufic inscription may have been used to suggest that the textile came from the Holy Land. So while in some cases Arabic inscriptions would have been imported as parts of transferred objects, in others they were produced in European contexts and may have been used, as in the case of the textile-page, to stage an Eastern provenance.

In the third case, addressed by Isabelle Dolezalek, Arabic inscriptions on Norman textiles combine textual and visual elements of various traditions, while at the same time referring to local legal practice with the aim of demonstrating royal authority. The example of the use of Arabic script, which has been extracted here from the range of elements discussed in these articles-including rock crystal vessels, ivory, textiles and manuscripts - may therefore serve to illustrate the very different functions for which Islamicate elements have been drawn upon in European arts.

Both the North European examples cited here demonstrate, moreover, that fictional relations can be more decisive for the use of Islamicate forms than factual ones. This emphasis on fictional relations also raises the question as to the relevance of a material transfer of an object for the reception of Islamicate elements in European contexts. It may be significant, therefore, that the objects focused on in this volume, which in modern art historical research are conceived as Islamicate on the basis of their provenance, were rarely considered to be such in pre-modern contexts.

In this regard, Tom Nickson asks whether the Islamicate forms of the triforium of Toledo Cathedral refer to the canonical masterpiece of 
the Great Mosque of Corboba, whether they rather point to later and local models, actually less imbued with references to Islam than to the Crusaders, or whether they have no precise model at all, but rely on a collective memory of various forms. Moreover, such associations can change over time, for example, between two generations of patronage within the same family, as is shown by Elena Paulino Montero.

Her article further stresses the degree to which the perception of Islamicate forms was determined by power relations, for example, between different rulers or between nobility and court. This points to the importance of complementing a formal history of style with a contextual analysis of the politics of style. However, the distribution of styles was not, of course, confined to historiographically proclaimed borders; the political and economical power relations in which individuals were acting were not clear-cut, so that a social rather than an imperial history of style - and of Islamicate style - is required. Alicia Walker addresses the social function of style by assessing the information which lead seals with Islamicate motifs provided about their Byzantine owners. Some of them, for example, suggest that their owner desired to be seen as a transregionally active merchant or as a member of a cosmopolitan court. So while style has often been used to categorise works, it is used here to evoke specific associations. Matters of style are thus not to be understood as matters of influence, but as matters of choice. ${ }^{23}$

\section{References}

Abdellatif, Rania, Yassir Benhima, Daniel König and Elisabeth Ruchaud (eds). 2011. Construire la Méditerranée, penser les transferts culturels: Approches historiographiques et perspectives de recherche, Munich.

Appadurai, Arjun (ed.). 1986. The Social Life of Things: Commodities in Cultural Perspective, Cambridge.

${ }^{23}$ The idea for this volume arose during the forum for young researchers, Linking Islamic and Christian Art: Transfer and Comparison (Berlin, June 2010), organised by the DFG Emmy Noether Junior Research Group, 'Kosmos/Ornatus. Ornaments in Persia and France c. 1400 in Comparison'. We would like to thank all speakers and participants for their stimulating contributions and for their openness and enthusiasm in the discussions. We also extend our gratitude to the DFG for its financial support and to Edward Street and Joana Mylek, whose comments and help have been invaluable.

- The Medieval History Journal, 15, 2 (2012): 231-242 
Behrens-Abouseif, Doris. 2007. 'Beyond the Secular and the Sacred: Qur'anic Inscriptions in Medieval Islamic Art and Material Culture', in Fahmida Suleiman (ed.), Word of God, Art of Man, Oxford: 41-49.

Berti, Graziella. 2004. 'La testimonianza delle ceramiche importate ed esportate', in Marco Tangheroni (ed.), Pisa e il Mediterraneo: Uomini, merci, idee dagli Etruschi ai Medici, Milano: 168-73.

Braudel, Fernand. 1949. La Méditerranée et le monde méditerranéen à l'époque de Philippe II, Paris.

Brubacker, Leslie. 2004. 'The Elephant and the Ark: Cultural and Material Interchange across the Mediterranean in the Eighth and Ninth Centuries', Dumbarton Oaks Papers, vol. 58: 175-95.

Caskey, Jill, Adam S. Cohen and Linda Safran (eds). 2011. 'Confronting the Borders of Medieval Art', Medieval Encounters, vol. 17.

Contadini, Anna. 2010. 'Translocation and Transformation: Some Middle Eastern Objects in Europe', in Lieselotte E. Saurma-Jeltsch and Anja Eisenbeiss (eds), The Power of Things and the Flow of Cultural Transformation: Art and Culture between Europe and Asia, Berlin and Munich: 42-65.

Creswell, Keppel Archibald Cameron. 1958. A Short Account of Early Muslim Architecture, rev. ed. James Allan, Cairo.

Dodds, Jerrilynn D. 1993. 'Islam, Christianity, and the Problem of Religious Art', in Jerrilynn D. Dodds (ed.), The Art of Medieval Spain A.D. 500-1200, New York: 27-37.

Drury Fortnum, Charles. 1870. 'Notes on the "Bacini", or Dishes of Enamelled Earthenware, introduced as Ornaments to the Architecture of some of the Churches in Italy', Archaeologia, vol. 42(2): 379-86.

Eckert, Andreas and Sebastian Conrad. 2007. 'Globalgeschichte, Globalisierung, multiple Modernen: Zur Geschichtsschreibung der modernen Welt', in Sebastian Conrad, Andreas Eckert and Ulrike Freitag (eds), Globalgeschichte: Theorien, Ansätze, Themen, Frankfurt: 7-49.

Flood, Finbarr Barry. 2001. 'The Medieval Trophy as an Art Historical Trope: Coptic and Byzantine "Altars" in Islamic Contexts', Muqarnas, vol. 18: 41-72.

- 2009. Objects of Translation: Material Culture and Medieval 'Hindu-Muslim' Encounter, Princeton.

Grabar, Oleg. 1997. 'The Shared Culture of Objects', in Henry Maguire (ed.), Byzantine Court Culture from 829 to 1204, Dumbarton Oaks: 115-30.

Hodgson, Marshall. 1974. The Venture of Islam, Conscience and History in a World Civilisation, vol. 1: The Classical Age of Islam, Chicago.

Hoffman, Eva. 2001. 'Pathways of Portability: Islamic and Christian Interchange from the Tenth to the Twelfth Century', Art History, vol. 24(1): 17-50.

Lézine, Alexandre. 1966. Architecture de l'Ifriqiya: recherches sur les monuments Aghlabides, Paris: 11-52.

Marçais, Georges. 1954. Architecture musulmane d'Occident, Paris: 9-22.

Müller-Wiener, Martina. 2008. 'Im Kontext gesehen: Die Artukiden-Schale und das “classical revival" in Nordsyrien und Gazira', in Martina Müller-Wiener and Ulrike Koenen (eds), Grenzgänge im östlichen Mittelmeerraum: Byzanz und die islamische Welt vom 9. bis 13. Jahrhundert, Wiesbaden: 147-68. 
Müller-Wiener, Martina and Ulrike Koenen. 2008. 'Prolog zum Thema Grenzgänge', in Martina Müller-Wiener and Ulrike Koenen (eds), Grenzgänge im östlichen Mittelmeerraum: Byzanz und die islamische Welt vom 9. bis 13. Jahrhundert, Wiesbaden: 9-26.

Nelson, Robert. 2005. 'Letters and Language: Ornament and Identity in Byzantium and Islam', in Irene A. Biermann (ed.), The Experience of Islamic Art on the Margins of Islam, Los Angeles: 61-88.

Ousterhout, Robert and D. Fairchild Ruggles (eds). 2004. 'Encounters with Islam: The Medieval Mediterranean Experience', thematic issue of Gesta, vol. 43(2).

Robinson, Cynthia and Leyla Rouhi (eds). 2005. Under the Influence: Questioning the Comparative in Medieval Castile, Leiden and Boston.

Schmidt Arcangeli, Catarina and Gerhard Wolf (eds). 2010. Islamic Artefacts in the Mediterranean World: Trade, Gift Exchange and Artistic Transfer, Venice.

Shalem, Avinoam. 2004. 'Objects as Carriers of Real or Contrived Memories in a Crosscultural Context: The Case of Medieval Diplomatic Presents', in Petra Stegmann and Peter C. Seel (eds), Migrating Images: Producing, Reading, Transporting, Translating, Berlin: 36-52.

- 2008. 'The Second Life of Objects: Ivory Horns in Medieval Church Treasuries', in Gudrun Bühl, Anthony Cutler and Arne Effenberger (eds), Spätantike und byzantinische Elfenbeinbildwerke im Diskurs, Wiesbaden: 225-36.

Smith, Christine. 1978. The Baptistery of Pisa, New York.

Tronzo, William. 2001. 'The Mantle of Roger II of Sicily', in Stewart Gordon (ed.), Robes and Honor: The Medieval World of Investiture, New York: 241-54.

_ 2003/04. 'Regarding Norman Sicily: Art, Identity and Court Culture in the Later Middle Ages', in David Knipp (ed.), Art and Form in Norman Sicily: Proceedings of an International Conference, Rome, 6-7 December 2002, Römisches Jahrbuch der Bibliotheca Hertziana, vol.35 (2003/04), Munich: 103-14.

Walker, Alicia. 2008. 'Meaningful Mingling: Classicizing Imagery and Islamicizing Script in a Byzantine Bowl', Art Bulletin, vol. 90(1): 32-53.

Wolf, Gerhard. 2009. 'Alexandria aus Athen zurückerobern? Perspektiven einer mediterranen Kunstgeschichte mit einem Seitenblick auf das mittelalterliche Sizilien', in Margit Mersch and Ulrike Ritzerfeld (eds), Lateinisch-griechisch-arabische Begegnungen: Kulturelle Diversität im Mittelmeerraum des Spätmittelaters, Berlin: 39-62.

Zeitler, Barbara. 1994. 'Cross-cultural Interpretations of Imagery in the Middle Ages', The Art Bulletin, vol. 76(4): 680-94.

\section{Illustrations}

Figure 1 Bacino fragment, Pisa, Santa Cecilia. In Fortnum, Charles. 1870. 'Notes on the "Bacini", or Dishes of Enamelled Earthenware, introduced as Ornaments to the Architecture of some of the Churches in Italy', Archaeologia, vol.42: 383.

Figure 2 Lustre-tiles, Great Mosque of Kairouan, detail of the mihrāab. (C) Erich Lessing, akg Images.

Figure 3 Great Mosque of Kairouan, mihrāb. (C) Erich Lessing, akg Images.

Figure 4 Santa Cecilia, Pisa, façade with bacini. (C) Sailko

- The Medieval History Journal, 15, 2 (2012): 231-242 